\title{
STRATIFIKASI SOSIAL (SISTEM SOSIO KULTUR) MASYARAKAT SASAK DI KABUPATEN LOMBOK TIMUR NUSA TENGGARA BARAT
}

\author{
DEWITA HARTATI \\ Pendidikan Sosiologi Universitas Hamzanwadi Selong, dewitahartati@yahoo.com
}

\section{INFO ARTIKEL}

RiwayatArtikel:

Diterima: 04-1 1-2016

Disetujui: 02-12-2016

Kata Kunci:

1. Stratifikasi sosial

2. Masyarakat

3. Suku Sasak

\begin{abstract}
Abstrak: Tulisan ini berusaha menkaji tentang bagaimana sistem sosio kultur pada masyarakat suku Sasak di Lombok Timur-NTB terutama pada masyarakat feodal dan kekinian. Penelitian ini menggunakan desain kualitatif. Wawancara digunakan sebagai teknik pengumpulan data yang dilakukan di lokasi penelitian yaitu di kabupaten Lombok Timur Nusa Tenggara Barat. Kajian pustaka jua digunakan untuk dijadikan data pembanding dari data primer. Data hasil wawancara dan kajian pustaka dilakukan analisis untuk menarik kesimpulan. Hasil kajian dapat disimpulkan bahwa suprastruktur idiologi pada masyarakat sasak feodal, idiologi umum yang mereka yakini mengarah pada keyakinan akan kosmologi yang menyatu dengan dirinya. Sedangkan dalam ilmu pengetahuan mereka mengembangkannya melalui wadah pengajaran sifat dan sikap yang patuh pada norma adat-istiadat yang berlaku dalam kehidupan masyarakat. Dalam bidang kesusastraan mereka mengenal lakak, cilokak dan cerita rakyat. Begitu juga dengan agama selalu menjadi pandua hidup mereka baik dalam urusan keduniaan lebih lebih untuk urusan alam baka. Struktur sosial masyarakat pada masyarakat sasak terdapat juga stratifikasi sosial, baik antara sesama maupun stratifikasi dengan etnis yang berbeda.

This paper attempts to examine the socio-cultural system of the Sasak people in East Lombok-NTB especially in feudal and contemporary society. This research uses qualitative design. Interviews were used as data collection techniques conducted at research sites in the district of East Lombok West Nusa Tenggara. The literature review is used to be used as comparative data from the primary data. Data from interviews and literature review were analyzed to draw conclusions. The results of the study can be concluded that the ideological superstructure of the feudal sasak society, the general ideology which they believe leads to the belief in cosmology that is united with itself. While in science they develop it through the teaching container of the nature and attitude that adheres to the norms of customs that prevail in the life of the community. In the field of literature they know lakak, cilokak and folklore. Likewise with religion always pandua their life both in mundane affairs more more for the affairs of the afterlife. Social structure of society in society sasak there is also social stratification, both between fellow and stratification with different ethnic.
\end{abstract}

ABSTRAK

\section{A. LATAR BELAKANG}

Kebudayaan yang terdapat di dalam masyarakat sangat beragam, diantaranya berupa kepercayaan, adat istiadat dan nilai-nilai sosial budaya yang mengikat dalam masyarakat. Selain itu juga terdapat unsur atau nilai religi yang merupakan tradisi atau warisan leluhur. Budaya spiritual, adat istiadat dan nilai kepercayaan yang sudah menjadi tradisi leluhur dan nenek moyang yang merupakan bentuk prilaku yang dilakukan secara terus menerus dan akhirnya dilakukan juga oleh masyarakat atau generasi berikutya.

Komponen dasar dari sistem sosio kultur adalah suprastruktur idiologis, struktur sosial dan infrastruktur material. Keberadaan komponen-komponen dari sistem sosio kultur ini beserta bagian-bagiannya walaupun dalam spasial yang sama namun tidak akan kita dapatkan pada waktu yang sama. Misalnya bagaimana komponenkomponen ini diterapkan pada masa feodal, pada masyarakat yang pra industri atau bahkan pada masyarakat yang saat ini kita kenal dengan masyarakat industri.

Pada masyarakat suku Sasak di Lombok-Nusa Tenggara Barat misalnya jika di tinjau sejarahnya terutama pada masa masyarakatnya yang feodal dan sedikit dapat kita lihat saat ini di daerah pedesaan sebagai kelanjutan dari sistem sosio kultur masyarakat feodal, walaupun saat ini keberadaannya sedikit demi sedikit mengalami perubahan, namun paling tidak sebagian ciri 
tersebut masih ada, dan inilah yang dapat kita lihat sebagai miniatur sosio kultur masyarakat feodal sebelumnya.

Seiring dengan perkembangan teknologi, manusia merasakan ketidak asliannya dan hanya menjadi budak mesin, dengan begitu tidak menutup kemungkinan orang akan mencoba memahami masa lampau sosio kulturnya yang dapat di katakana masih asli, dimana pada saat itu antara alam dan manusianya memiliki sinergisitas kekuatan yang masing-masing saling menerima dan memberi. Dimana ikatan sosial antara keluarga, kerabart dan masyarakat sekitar sangat tinggi dan berbagai kegiatan sosial masyarakat yang penuh dengan kebersamaan. Karena itu kami akan coba mengkaji bagaimana sistem sosio kultur pada masyarakat suku Sasak di Lombok Timur-NTB terutama pada masyarakat feodalnya dan kekinian.

\section{B. METODE PENELITIAN}

\begin{tabular}{rrr} 
Penelitian & ini & \multicolumn{2}{c}{ menggunakandesain } \\
penelitiankualitatif dengan metode wawancara.
\end{tabular}
Wawancara dilakukan di lokasi penelitian yaitu di kabupaten lombok timur nusa tenggara barat. Tenknik penggumpulan data yaitu wawancra langsung dengan narasumber yang telah ditentukan diawaldankajian pustaka yang relevan dengan subjek penelitian. Selanjutnya data hasil wawancara dan kajian pustakan dilakukan analisis untuk menemukan jawaban atas pertanyaan penelitian diatas.

\section{HASIL DAN PEMBAHASAN}

\section{Suprastruktur Idiologi Masyarakat Sasak di Kab. Lombok Timur}

Dalam pengertian Karl Marx bahwa suprastruktur berarti semua produksi yang bersifat non-materi yang berasal dari ide masyarakat antara lain misalnya, lembagalembaga politik, hukum, atau undang-undang, agama, pemikiran, filsafat,dan etika. Dengan kata lain bahwa suprastruktur bukanlah sesuatu yang muncul sendiri. Karena ia muncul sebagai 'produk' sebuah ide (gagasan).

Adapun beberapa suprastruktur idiologi pada masyarakat Sasak di pulau Lombok terutama dalam tinjauan sejarahnya yang muncul dan perlu kita bahasas di bawah ini adalah sebagai berikut:

\section{a. Idiologi Umum}

Kesatuan antara dirinya dengan alam yang di sebut kosmologi merupakan idiologi umum yang berkembang pada masyarakat tradisional suku Sasak. Kosmologi menghendaki perasaan kesatuan antara manusia dengan alam sehingga alam memiliki kekuatan yang harus manusia ikuti baik dengan menjaga lingkungan alam yang lebih leastari sampai pada pemberian sesajian untuk alam.

Bukan hanya kesatuan dengan alam yang menjadi idiologi umum masyarakat, melainkan kepatuhan mereka pada orang tua, saudaranya yang lebih tua, yang jikalau mereka di lawan baik dengan kata-kata atau perbuatan. Jika mereka melawan di yakini mereka akan bernasip kurang baik, apabila sampai mereka di sumpahi. Perasaan saling membutuhkan bersama antara individu yang satu dengan yang lainnya adalah idiologi umum. Namun jelas yang menyatukan mereka adalah idiologi mereka yang lebih besar yaitu adanya kosmologi.

\section{b. Ilmu Pengetahuan}

Ilmu Pengetahuan yang di tularkan dari orang tua atau masyarakat yang tradisional cendrung mengarah pad aide-ide yang kurang rasional. Namun juga di lain hal anak-anak akan terus di ajarkan bagaimana bersikap sopan santun dengan orang tua, orang yang lebih dewasa dan bagaimana cara bergaul dalam kehidupan sosial berdasarkan norma-norma yang berlaku pada saat itu.

Pada masyarakat suku Sasak tradisional, dalam kehidupan sehari-hari diajarkan bagaimana menjadi orang yang rit (sesuai dengan norma adat-istiadat yang berlaku) yang di junjung tinggi bersama, sehingga hal ini juga mengarah pada adanya kolektivitas sosial masyarakat yang tinggi.

\section{c. Kesusastraan}

Masyarakat sasak tradisional sebelum mereka mengenal tulisan yang sampai saat ini banyak kita lihat pada generasi tua, mengenal namanya lakak (pantun), nyanyian tradisional sampai cerita-cerita pengaruh kebudayaan Hindu-Budha yang di rubah setingg ceritanya di Pulau Lombok oleh pengerang yang tidak di kenal (anonim).

Lakak dan nyanyian ini biasanya sangat di gemari oleh masyarakat karena dapat berfungsi sebagai alat 
pelipur lara di tengah sawah atau tempat mereka bekerja, karena dengan cara bersama-sama dapat bernyanyi atau saling membalas pantun. Bukan hanya itu, fungsi pantun juga untuk menyindir ketika seorang laki-laki berkeinginan untuk menjadikan tambatan hati pada seorang perempuan. Karena pada saat itu tabu bagi masyarakat jika perempuan yang terlebih dahulu mengutarakan isi hatinya pada seorang lelaki.

Adapun cerita-cerita rakyat di sampaikan melalui teradisi lisan terutama ketika anak menjelang tidur. Sebelum anak-anak tidur, terlebih dahulu mereka akan di ceritakan bagaimana perjuangan raja ini dan itu, perjuangan seseorang melawan raksasa dan lain sebagainya. Namun pada intinya tradisi lisan ini lbeih banyak menceritakan seorang tokoh besar yang mampu mengubah situasi sosial secara keseluruhan. Beberapa cerita rakyat yang terkenal pada suku sasak misalnya cerita Cuplak Gerantang, tuak tegodek-godek dan lain sebagainya.

\section{d. Agama}

Christopher Dawson (Soejatmoko dkk, 1995) mengatakan bahwa "agama adalah kunci sejarah. Kita tidak dapat memahami bentuk dalam diri satu masyarakat jika kita tidak memahami agama. Kita tidak dapat memahami hasil kebudayaannya jika kita tidak memahami kepercayaan agama yang ada di sekitar mereka. Dalam semua zaman, hasil karya kreatif pertama dari suatu kebudayaan muncul dari inspirasi agama dan di abdikan pada tujuan keagamaan.

Masyarakat Lombok terkenal dengan religiusitasnya yang tinggi. Hal ini mencerminkan bagaimana mereka seharusnya bertindak baik untuk tujuan hidup mereka yang sementara di muka bumi ini maupun tujuan mereka pada kehidupan yang abadi dan kekal di ahirat nanti. Masyarakat tradisional suku Sasak di katakana harus rit dimana tidak boleh menyimpang dari ajaran agama dan adat-istiadat yang berlaku. Dengan demikian dalam perilaku hidup mereka mengarah pada bagaimana tujuan keagamaan bisa tercapai supaya mereka mendapatkan surge di alam ahirat nanti. Berdasarkan ajaran agama ini mereka akan memiliki rasa identitas bersama yang lebih besar.

\section{e. Kesenian}

Banyak sekali kesenian teradisional masyarakat sasak yang sampai saat ini masih terus di lestarikan. Salah satunya adalah wayang, rudat, jangger dan yang peling terkenal adalah peresean. belum lagi ada keseniankesenian masyarakat dalam lingkungan yang lebih kecil berupa permainan anak-anak orang dewasa dan lain sebagainya.

J.J. Branedes mengelompokkan ketiga kesenian yang di sebut di atas, baik wayang, rudat dan jangger merupakan budaya asli Indonesia yang mana dalam pencritaannya selalu berbeda antara daerah yang satu dengan daerah yang lain. Namun husus pada masyarakat Sasak terdapat kesenian tradisional yang sampai saat ini terus di lestarikan, bahkan untuk terus melestarikan salah satu kesenian asli masyarakat Sasak ini pemerintah turun tangan untuk menggelar pestifal peresean ini.

Peresean merupakan kesenian rakyat tradisional di Lombok yang bertujuan untuk melatih kekuatan fisik, kejelian dan kekuatan mantra di samping arti sosial lainnya. Dimana dua orang laki-laki di adu untuk bertarung menggunakan penyale (rotan) untuk memukul lawan dan sebuah ende (prisae) untuk menahan pukulan lawan. Di tengah kerumunan orang banyak terdapat pengembar (juri) yang akan menengahi kedua orang yang akan perese tersebut.

\section{Struktur Sosial Masyarakat Sasak di Kab. Lombok Timur}

\section{a. Stratifikasi Sosial}

Pemahaman antara stratifikasi sosial dan kelas sosial sering kali disamakan, padahal di sisi lain pengertian antara stratifikasi sosial dan kelas sosial terdapat perbedaan.Stratifikasi sosial lebih merujuk pada pengelompokan orang ke dalam tingkatan atau strata dalam hierarki secara vertikal. Membicarakan stratifikasi sosial berarti mengkaji posisi atau kedudukan orang-orang atau kelompok orang dalam keadaan yang tidak sederajat. Dengan demikian, stratifikasi sering kali dikaitkan dengan persoalan kesenjangan atau polarisasi sosial (Elly Setiadi \& Usman Kolip, 2011: 400).

Pitirim A. Sorokin seperti dikutip Soerjono Soekanto (2006) menyatakan bahwa social stratification adalah pembedaan penduduk atau masyarakat ke dalam kelas-kelas secara bertingkat (hierarkis). Perwujudannya 
adalah kelas-kelas tinggi dan kelas-kelas rendah. Selanjutnya menurut Sorokin, dasar dan inti lapisan sosial masyarakat tidak adanya keseimbangan dalam pembagian hak dan kewajiba, kewajiban dan tanggung jawab nilainilai sosial dan pengaruhnya diantara anggota-anggota masyarakat.

Dari sedikit penjelasan di atas maka jelas dalam setiap masyarakat baik yang masih peodal sampai sampai masyarakat demokrasi saat ini, kita akan terus malihat adanya stratifikasi sosial dalam kehidupan masyarakat, dan ini memang sudah merupakan keharusan yang membuat perkembangan masyarakat menjadi progress. Namun jelas stratifikasi sosial yang kita butuhkan adalah stratifikasi yang sifatnya terbuka (open social stratification) bukan pelapisan sosial tertutu (closed social stratification) seperti pada masyarakat peodal.

Dengan demikian maka pada bagian ini kami tidak akan mengilas tentang bagaimana stratifikasi sosial terbuka melainkan stratifikasi sosial tertutup yang pernah mewarnai kehidupan masyarakat Sasak di Lombok Timur pada masa kerajaan sampai sekitar tahun 50-an. Hal ini kami lakukan untuk bisa mendapatkan gambaran seperti apa stratifikasi sosial pada masyarakat peodal di Lombok Timur. Yang notabenenya saat ini sama dengan masyarakat di daerah lain yang mana sudah berkembang pada tataran stratifikasi sosial masyarakatnya yang terbuka (open social stratification).

Adapun beberapa ciri dari stratifikasi sosial pada umumnya, sekaligus sebagai penjelas ciri stratifiksi masyarakat fedal pada masyarakat Sasak di Lombok, terlebih husus di Lombok Timur, yaitu:

1) Keanggotaan pada kasta di peroleh karena kewarisan/ kelahiran, anak yang lahir memperoleh kedudukan orang tuanya.

Pada masyarakat Sasak di Lombok Timur pada zaman kerajaan dan sampai kira-kira tahun 50-an bahkan sebagian kecil sampai saat ini, mengenal juga strata sosial sama seperti masyarakat feodal pada umumnya. Kedudukan seseorang dalam setrata sosial sifatnya tertutup dan akan terwariskan dari generasi-ke generasi. Hal ini terbukti dari adanya gelar yang selalu melekat pada anak-anak mereka. Kemungkinan untuk naik setrata sosialnya mungkin sangat sedikit, kecuali mungin memiliki jasa besar dalam kerajaan misalnya pada masa kerajaan. Namun pada umumnya lebih banyak terjadi penurunan strata sosial, hal ini di akibatkan oleh aturan dalam system perkawinan yang sifatnya endogamy (hal ini akan di jelaskan belakangan).

Status dan gelar yang akan di dapatkan oleh seorang anak pada masyarakat bangsawan di Lombok mengikuti garis keluarga ayah, atau yang di sebut sistem kekeluargaan yang faterialistik. Walaupun dalam status kekeluargaan ibunya memiliki tingkat strata sosial yang lebih tinggi dari ayahnya namun dia tidak akan pernah mendapatkan strata sosial ibunya tersebut dan harus mendapatkan setrata sosial seperti ayahnya.

Demikian juga pada masyarakat biasa atau di Lombok di kenal dengan nama Jajarkarang. Walaupun mereka kawin dengan seorang bangsawan anaknya tidak akan mendapatkan strata sosial sebagai seorang bangsawan. Karena jika seorang perempuan menikah dengan laki-laki yang status sosialnya lebih rendah maka strata sosial wanita tersebut yang sebelumnya sebagai bangsawan akan berubah statusnya seperti masyarakat jajarkarang pada umumnya. Dengan demikian maka jelas bahwa pada masyarakat feodal di Lombok status sosial akan di turunkan secara turun temurun, dan dari satu generai ke generasi setelahnya dengan mengikuti garis keturunan dari ayahnya.

2) Keanggotaan yang di wariskan tadi berlaku seumur hidup, oleh karena seseorang tak mungkin mengubah kedudukannya, kecuali bila ia dikeluarkan dari kastanya.

Seperti kami jelaskan pada bagian pertama bahwa pada umumnya masyarakat feodal di pulau Lombok menggunakan ikatan sosial yang fatrialistik, atau mengikuti kekerabatan dari status kekeluargaan ayahnya. Dengan begitu status sosial yang di miliki oleh ayah akan terus melekat padanya sampai seumur hidupnya. Terkecuali bagi seorang perempuan, walaupun mereka berasal dari keluarga bangsawan, namun menikah dengan laki-laki yang berasal dari keluarga bangsawan yang lebih rendah atau mungkin juga dengan masyarakat jajarkarang, maka perempuan tersebut akan mengikuti status sosial dari suaminya. Karena itu pada masyarakat Lombok pada masyarakat feodalnya dalam hal keberlakuan status sosial 
yang berlaku seumur hidup lebih condong pada kedudukan laki-laki dan bukan perempuan.

3) Perkawinan bersifat endogami, artinya harus di pilih dari orang yang sekasta.

Perkawinan endogami adalah sistem perkawinan yang mengharuskan seseorang menikah dengan orang yang memiliki status kekerabatan dengan dirinya terutama perupa kesamaan status sosial. Masyarakat Sasak di Lombok terutama bengsawan sangat memperhatikan masalah ini. Karena jika anaknya kawin dengan orang yang memiliki kesamaan status maka akan lebih meningkatkan prestisenya, karena dengan menikan sesama satu strata sosial tidak akan menyebabkan status sosial anaknya menurun, terutama bagi perempuan. Sehingga terutama bagi bangsawan yang cukup ketat peraturannya sampai saat ini pemilihan jodoh untuk anak perempuannya masih ada. Atau paling tidak perempuan tersebut akan di anjurkan untuk menikan dengan laki-laki dari keluarga besar ayah atau ibunya.

4) Hubungan dengan kelompok-kelompok sosial lainnya bersifat terbatas

Salah satu yang menarik sebagai contoh kecil akan hal ini adalah pengelompokan golongan bangsawan di Kecamatan Jerowaru. Di Desa Jerowaru Lombok Timur terdapat dua tempat konsentrasi bangsawan yang memisahkannya dengan golongan rakyat biasa. dan sisasisa bangunannya dapat kita lihat sampai saat ini. Gubuk tembok yang di lingkari dengan batasan dan Gubuk pedaleman di Jerowaru mengindikasikan adanya pengkonsentrasian secara sosial dengan strata sosial yang sama, yang artinya hubungan mereka dengan golongan sosial yang berada di bawahnya relatif kurang.

5) Kesadaran pada keanggotaan suatu kasta yang tertentu, terutama nyata dari nama kasta, identifikasi anggota pada kastanya, penyesuaian diri yang ketat terhadap norma-norma kasta dan lain sebagainya.

Beberapa gelar kebangsawanan yang sampai saat ini masih melekat pada masyrakat sasak diantaranya adalah Raden (laki-laki) dan Lale (perempuan) untuk tingat sosial yang peling tinggi dan kedudukannya beradi di bawah datu dan pembesar istana lainnya pada masa dulu. Setelah gelar di atas terdapat setrata sosial di bawahnya yaitu yang bergelar Lalu (laki-laki) dan Baiq atau Dende (perempuan). Adapun di tempat lain juga ada gelar Bape, dimana strata sosialnya berada di bawah Lalu atau Mamik (sebutan lalu yang sudah memiliki keluarga atau anak). Kemudian menyusul di bawahnya golongan Jajarkarang (rakyat biasa).

Gelar yang di miliki seseorang dalam tingkatan sosial tertentu akan terus di terima oleh keturunannya turutama dari keturunan yang laki-laki dan akan dapat berubah bagi keturunannya jika seorang laki-laki biasa menikah dengan wanita yang strata sosialnya dua tingkat lebih tinggi dari status sosialnya. Namun yang jelas adalah mereka lebih mengutamakan keturunan dari keluarga ayahnya atau sistem kekeluargaan yang faterialistik.

6) Kasta di ikat oleh kedudukan-kedudukan yang secara tradisional telah di tetapkan.

7) Prestise suatu kasta benar-benar di perhatikan.

\section{b. Stratifikasi Rasial dan Etnis}

Berdirinya kerajaan-kerajaan di Lombok baik kerajaan asli maupun kerajaan yang di pengruhi oleh budaya luar seperti Kerajaan Selaparang, Pejanggik, Pujut, Langko, dan lain sebagainya jelas memiliki koneksi dengan kerajaan yang berada di luar pulau Lombok. Hal inilah yang menyebabkan terjadinya akulturasi budaya dan kadang-kadang sampai pada imigrasi dari daerah lain ke pulau Lombok. Dengan begitu di Lombok di kenal beberapa etnis yang ada selain etnis sasak yang jumlahnya hampir 95\% dari keseluruhan jumlah etnis yang ada. Etins yang berbeda tersebut berasal dari Bugis (Makassar) yang lebih banyak tinggal di pesisir pantai, seperti di Labuhan Lombok, Labuhan Haji, Tanjung Luar dan lain sebagainya, kebanyakan mereka berprofesi sebagai nelayan. Secara ekonomis di bandingkan dengan penduduk asli yang berprofesi sebagai nelayan mereka lebih tinggi penghasilannya kerena mereka merupakan nelayan yang giat sekaligus menjadi saudagar yang membeli hasil tangkapan masyarakat nelayan di tempat tinggalnya.

Selain etnis Bugis, ada juga yang berasal dari timur tengah yang kebanyakan berprofesi sebagai pedagang. Tidak ketinggalan juga orang-orang Jawa dan Bali yang datang untuk tinggal menetap di pulau Lombok. Namun yang menarik perhatian selanjutanya adalah keberadaan orang-orang cina yang secara ekonomis merupakan kelas ke dua setelah orang eropa pada masa penjajahan, hal ini juga samaberlakunya dengan orangorang timur tengah yang di katakana merupakan kelas ke dua setelah orang-orang eropa. 
Namun walaupun terdapat banyak etnis yang mendiami pulau ini dan di dominasi oleh suku Sasak yang beragama Islam, jarang sekali kita mendengar adanya konflik etnis, kecuali terdapat hal-hal kerusial yang memicunya. Contoh kasus pengusiran etnis cinta oleh orang-orang Labuhan Haji merupakan konflik etnis yang nyata, hal ini bukan saja di karenakan adanya pengumuman pemerintah akan adanya pemberontakan PKI di pusat. Karena peristiwa pengusiran etnis Cina di Labuhan Haji tidak lama berselang setelah pengumuman pemberontakan PKI di Jakarta. Pengusiran ini lebih banyak di picu karena adanya kecemburuan sosial oleh penduduk setempat yang di hasut, sehingga pengusiran tidak terhindarkan. Secara ekonomis jelas mereka memiliki posisi sosial lebih tinggi di bandingkan dengan masyatrakat asli pada umumnya, begitu juga dengan ststus ekonomi yang di miliki oleh orang-orang yang berasal dari Timur Tengah. Mereka bukan hanya sebagai agen pembeli hasil pertanian dan nelayan oleh penduduk asli namun mereka juga memiliki pabrik serta heler untuk memproses padi menjadi beras di saat orang pribumi tidak ada satu pun yang memiliki. Karena itu penguasaan mereka atas sector ekonomi ini, sekaligus adanya isu nasional tentang pengganyangan PKI membuat mereka harus terusir dari Labuhan Haji ke kawasan Cakra Negara di Lombok Barat sekarang.

\section{c. Pembagian Kerja Secara Seksual}

Masyarakat tradisional suku Sasak tidak berbeda dengan masyarakat tradisional di darah lain yang memberikan pekerjaan pada wanitanya pada sektor domestik. Karena di asosiasikan dengan pekerjaan rumah seperti tugas memasak, melayani uami dan mengurus anak serta pekerjaan sawah atau lading yang tidak terlalu berat seperti menanam padi dan lain sebagainya. Sedangkan bagi laki-laki condong untuk bekerja di luar rumah dan pekerjaannya tersebut membutuhkan tenaga yang besar seperti mencari kayu, mencangkul di sawah, dan lain sebagainya.

Dalam hal hal pembagian kerja, terkesan seorang perempuan pada masyarakat sasak tradisional terkesan berperan ganda. Dalam rumah tangganya dia berperan sangat dominan dalam pengurusan anak, mereka juga kegiatan sehari-harinya memasak untuk anak-anak dan suaminya, sekaligus mereka juga berpartisipasi dalam pekerjaan suaminya di sawah.

Sedangkan pekerjaan yang sifatnya formal mereka tidak akan mendapatkannya, karena dalam hal ini merupakan kewajiban laki-laki untuk bekerja si sektor tersebut. Mereka tidak akan mendapatkan kedudukan sebagai ketua adat, pejabat pemerintahan dan lain sebagainya.

\section{d. Keluarga dan Kekerabatan}

Sistem kekerabatan merupakan cara untuk mengatur atau cara dalam mengatur hubungan sesama keluarga, sanak famili, teman sejawat maupun teman kerja berdasarkan adanya aturan yang dibuat bersama secara turun temurun maupun berkala.

Karena itu dalam setiap masyarakat manusia, pasti akan di jumpai keluarga batih ("nuclear family). Keluarga batih tersebut merupakan kelompok sosial kecil yang terdiri dari suami, istri beserta anak-anaknya yang belum menikah. Keluarga batih tersebut lazimnya juga di sebut rumah tangga, yang merupakan unit terkecil dalam masyarakat sebagai wadah dan proses pergaulan hidup seperti di sebutkan di atas.

Suatu keluarga batih dianggap sebagai suatu sistem sosial, oleh karena memiliki unsur-unsur sistem sosial yang ada pada pokoknya mencakup kepercayaan, perasaan, tujuan, kaidah-kaidah, kedudukan, dan peranan, tingkatan atau jenjang, sanksi, kekuasaan dan fasilitas lainnya (Soerjono Soekanto, 2009: 1).

Berkaitan dengan keberadaan keluarga dan ikatan kekerabatan dalam suatu lingkungan sosial budaya pada masyarakat Sasak di Lombok terutama pada masyarakat feodal mempunyai ciri-ciri pokok, sebagai berikut:

\section{1) Hubungan dalam keluarga dan masyarakat setempat} atau komunitas sangat kuat.

Kolektivitas yang tinggi antara keluarga atau pun kerabat sangat tinggi pada masyarakat feodal di pulau Lombok. Hal ini sampai sekarang terbukti, dan bukan hanya pada masyarakatnya yang peodal. Pulau Lombok yang di juluki "Pulau Seribu Masjid" adalah realita kolektivitas masyarakatnya baik sebagai individu, keluarga, untuk menjadi bagian yang penting dari masyarakat sekitar di mana mereka tinggal. 
Dalam sistem kekerabatan terdapat kesatuan sosial yang mengatus sesamanya dalam satu rumpun sistem kekerabatan, sehingga walaupun anggotanya tidak tinggal dalam satu wilayah yang sama namun dia akan memberikan satu petunjuk bahwa dia memiliki hubungan kekerabatan dengan mereka yang tinggal di tempat yang berbeda tersebut. Contoh, pada masyarakat sasak di kenal istilah bebubus. Dimana di dalam acara bebubus ini kita akan mendapatkan adanya kekuatan sistem kekerabatan yang mengaturnya, sehingga walaupun berada di tempat jauh atau tinggal di tempat yang berbeda dia akan mencari induk bubus nenek moyangnya, sehingga bebubus lebih tepat di katakana di Lombok telah memperlihatkan adanya kekuatan sistem kekerabatan yang mengaturnya. Bebubus ini adalah salah satu contoh kecil namun tentu masih banyak contoh yang lainnya dan mungkain akan di bahas di tempat lain.

2) Kelompok-kelompok sosial dan organisasiorganisasinya didasarkan pada adat-istiadat yang terbentuk menurut tradisi.

Keluarga adalah ikatan terkecil yang menjadi pioner pengkulturasian tradisi dan di realisasikan dalam kehidupan kolektif masyarakat dalam lingkungan kekerabatan dan masyarakat pada umumnya. Pada masyarakat Sasak feodal dan sampai saat ini di sebagian kawasan terdapat tokoh adat yang berperan penting untuk terus menjaga keutuhan tradisi dari nenek moyangnya. Peranan tokoh adat merupakan salah satu ciri dari organisasi sosial masyarakat di pulau Lombok.

3) Kepercayaan yang kuat pada kekuatan-kekuatan gaib yang mempengaruhi manusia.

Kebiasaan orang tua untuk mewariskan kepercayaan akan adanya kekuatan-kekuatan gaib seperti jin, bakeq, beboro, selak, bebai, dan lain sebagainya selalu di mulai dari keluarga, sehingga dalam kekerabatan yang jangkauannya lebih besar hal tersebut akan terpatri, begitu juga halnya dengan kepercayaan sekitar tempat tinggal akan memiliki kepercayaan yang sama dengan yang lainnya. Kepercayaan pada kekuatan gaib pada bubus yang sekaligus sebagai perekat kekerabatan merupakan bukti kuat adanya kepercayaan bersama oleh masyarakat pada kekuatan-kekuatan gaib.
4) Keterampilan diwariskan oleh orang tua kepada anakanaknya, sambil berpraktek dengan sedikit teori dan pengalaman.

Keluarga merupakan tempat belajar pertama, dan lingkungan sosial adalah agen untuk menyempurnakan tujuan hidup bersama, antara tetangga baik sebagai satu keluarga, kerabat dekat, jauh dan lain sebgainya merupakan tempat pembelajaran pertama bagi anak-anak dan generasi sesudahnya. Peran keluarga pada generasi muda dan anak di Lombok sampai saat ini masih di rasakan sangat penting. Terutama di pedesaan dari sejak kecil mereka di ajarkan bagaimana bekerja di sawah, menjadi pengembala, mengetahui dan bertindak sopansatun dan lain sebagainya. Yang pada intinya mereka di ajar oleh orang tua mereka dan masyarakatnya yang mencerminkan kekerabatan yang lebih luas untuk memahami budaya materil dan spiritual dari masyarakat dan keluarga di mana tempatnya tinggal tersebut.

5) Hukum yang berlaku pada dasarnya tidak tertulis dan diketahui dan dimengerti oleh semua anggota masyarakatyang sudah dewasa.

Memang pada umumnya kehidupan masyarakat baik dalam lingkungan keluarga maupun masyarakat, terutama pada masyarakat feodal dan sampai saat ini di kehidupan masyarakat pedesaan di Lombok di kenal istilahnya awik-awik atau norma hukum masyarakat yang tidak tertulis namun jika hal tersebut di langgar maka akan mendapatkan hukum sosial dari masyarakat.

Untuk ukuran saat ini, jika di kontraskan dengan awik-awik masyarakat pada masa lalu, jelas banyak dari perilaku sosial kita yang pada saat itu merupakan hal yang tabu, dan itulah jika sesuatu yang tabu itu di langgar oleh salah seorang, maka bukan hanya dirinya saja yang akan mendapatkan hukuman sosial melainkan keluarga dan kerabat dekatnya. Mereka yang melanggar tidak di hokum namun dengan sendirinya mereka akan merasa di hokum oleh adanya norma hokum masyarakat yang mereka langgar tersebut.

6) Sistem ekonomi pada dasarnya mencakup produksi untuk kepentingan keluarga sendiri atau pasaran kecil setempat, sehingga uang sebagai alat pengukur harga atau alat pengukur peranannya sangat terbatas.

Tentu kita masih ingat ciri dari sistempertukaran masyarakat feodal adalah sistem barter yaitu barang dengan barang. Pada masyarakat Lombok dahulunya 
menggunakan trasnsaksi seperti itu juga. Bahkan hal ini masih berlaku sesudah kemerdekaan seperti yang di ceritakan oleh orang-orang tua. Bagi masyarakat yang tinggal di pinggir-pinggiran hutan biasanya membawa kayu bakar untuk di tukarkan dengan ubi jalar dan lain sebagainya.

\section{e. Pendidikan}

Tidak salah memang jika kemajuan suatu daerah, Negara, dan lain sebagainya baru di katakana maju jika dalam bidang pendidikannya juga maju. Masyarakat tradisional secara umum di Lombok Timur dalam hal pendidikan memang sangat kurang walaupun pada saat itu terutama setelah kedatangan Belanda telah tersedialembaga pendidikan yang di utamakan bagi para pembesar dan terutama bagi bangsawan. Namun karena ikatan keagamaan yang kuat, sekaligus juga sebagai antitesa dari penjajahan Belanda pada awalnya tidak sedikit putr-putra terbaik di Lombok ini yang mengenyam pendidikan ke luar daerah seperti ke Jawa, maupun keluar negeri seperti Arab Saudi, Mesir dan lain sebagainya. Mereka inilah yang memberikan pendidikan pada masyarakat pada awalnya baik berupa pendidikan formal dan pendidikan informal.

Lembaga pendidikan pertama di Nusa Tenggara Barat pada umumnya, dan Lombok Timur hususnya, di mulai semenjak Madrasah Nahdatul Wathan Diniah Islamiah oleh K.H. Muhammad Zainuddin Abdul Majid, seorang ulama besar di Pancor, Lombok Timur. Kemudian pada tahun 1943 M didirikan Madrasah Nahdlatul Banat Diniyah Islamiah. Madrasah ini bertujuan bagi pendidikan murid-murid putrid. Inilah sedikit keterangan tonggak pendidikan secara formal di Lombok Timur pada hususnya. Yang terlebih dahulu pendidikan secara tradisional lebih bersifat tertutup.

\section{Infrastruktur Material Masyarakat Sasak di Kab.} Lombok Timur

Infrastruktur merupakan merupakan wujud hasil dari suprastruktur yang bersifat ide. Infrastruktur dengan kata lain adalah sarana fisik (lahiriah) yang di sediakan manusia untuk menyelenggarakan kehidupan bermasyarakat; dalam rangka menunjang kegiatan politik, ekonomi, sosial, dan segala kebutuhan hidup lainnya. Terkait dengan pembahasan di atas, ada beberapa infrastruktur material masyarakat yang perlu kita bahas di bawah ini terkait dengan bagaimana infrastruktur material yang ada di Lombok Timur dalam lingkup kesejarahannya dan kekinian. Adapun beberapa infrastruktur material tersebut adalah sebagai berikut:

\section{a. Teknologi}

Beberapa macam sistem teknologi tradisional yang perlu di bahas pada bgian ini adalah berupa pakaian dan perhiasan, senjata, tempat berlindung dan perumahan, alat-alat transportasi, alat-alat menyalakan api, serta alat untuk kebutuhan makan dan minum sehari-hari mada masyarakat tradisional pada masyarakat Sasak di Lombok Timur hususnya.

\section{1) Perhiasan}

Perhiasan tradisional masyarakat sasak lebih banyak terbuat dari benda-benda alam di sekitarnya, bisa berupa terbuat dari kayu maupun hasil laut. Misalnya gelang yang di gunakan oleh perempuan terbuat dari benda laun yang di namakan akar batu berwarna hitam. Sedangkan pakaian tradisionalnya di sebut Lambung.

2) Senjata

Di Lombok di kenal juga senjata seperti Jungkat (tombak), panak (panah), keris), Berang (semacam golok), batek, dan lain sebagainya.

3) Rumah dan Perlengkapannya

Pembuatan rumah secara tradisional di kerjakan secara tradisional juga. Pondasinya terbuat dari tanah yang di campur dengan kulit padi serta di halusin dengan tahi kerbau, dan ini di lakukan hampir oleh semua masyarakat tradisional. Pembuatan rumah seperti ini masih kita dapatkan sampai sekarang di pedesaan seperti di Sade Lombok Tengah dan daerah Bayan di Lombok Timur. Rumah tersebut juga beratapkan ilalang serta bertembokkan bedek.

4) Alat-alat transportasi.

Alat transportasi masyarakat pada umumnya seperti cerita orang-orang tua tidak ada, karena jika ada terutama pada saat penjajahan hanya dimiliki segelintir penguasa terutama orang-orang kulit putih atau orangorang Belanda dan sedikit bangsawan yang bekerja untuk penjajah, atau paling tidak bangsawan yang memiliki kekayaan yang cukup banyak. Alat transportasi pertama bisa berupa kuda, kemudian sepeda.

5) Alat kebutuhan Makan dan Minum 
Sebelum masyarakat Sasak mengenal peralatan modern seperti saat ini, sebelumnya mereka menggunakan teknologi rumah tangga yang terbuat dari tanah liat yang di bakar. Untuk memasak nasi mereka menyebutnya dengan namapemongkak, sedangkan untuk penampungan air di sebut kurun, sedangkat untuk menggoreng sesuatu mereka membuat semacam kuali yang terbuat dari tanah juga di sebut kete. Sedangkan untuk penampungan air untuk mandi dan mencuci dan lain sebagainya di sebut bong.

\section{b. Ekologi}

Ekologi ini berkaitan dengan sumberdaya alam yang ada dan keterkaitannya dengan bagaimana masyarakat Sasak merealisasikannya dalam penggunaan hidupnya sehari-hari. Termasuk juga dalam hal ini bagaimana masyarakat memanfaatkan sumberdaya alam yang ada. Pada masyarakat tradisional yang mata pencahariannya sebagian besar adalah petani dan sebagian lagi adalah nelayan sudah barang tentu yang mereka butuhkan adalah bagaimana bisa menundukkan alam sehingga bisa menghasilkan hasil yang bagus yaitu dengan menggunakan apa yang tersedia di alam secara alami. Ketika mereka kekurangan tempat menanam, mereka akan dengan mudah mencari lahan baru dengan menebang hutan yang pada saat itu belum ada larangan untuk membukanya, karena tidak ada kepemilikan pribadi, dan siapa yang membuka hutan dialah yang akan memiliki lahan tersebut.

\section{c. Ekonomi}

Seperti di jelaskan di atas bahwa perekonomian masyarakat tradisional pada masyarakat Sasak berkisar pada pertanian dan nelayan, namun yang lebih dominan mereka adalah sebagai petani. Karena kebnyakan masyarakat nelayan sekaligus sebagai petani, hal ini sampai sekarang dapat kita lihat. Namun sebaliknya masyarakat yang notabenenya husus sebagai petani dan hidupnya jauh dari laut, jelas tidak akan berprofesi sebagai nelayan.

Hasil dari pertanian masyarakanya bukan hanya padi melainkan banyak kebutuhan hidup lainnya seperti jagung, ubi jalar, singkong dan lain sebagainya. Bhkan seperti cerita dari orang-orang tua, dalam hal pertukaran untuk mendapatkan barang yang berbeda, yaitu dengan cara barter. Masyarakat tradisional di Lombok juga tidak hanya makan nasi beras sebagai bahan makanan pokok, tetapi di campur juga dengan ubi atau bahkan dengan jagung yang di kenal oleh masyarakat luas dengan nama nasi jagung. Hal ini sekaligus di akibatkan kurang produktivnya aktivitas pertanian masyarakat. Baru setelah beberapa teknologi pertanian di perkenalkan oleh pemerintah, terutama sekali pada awal pemerintahan almarhum presiden Soeharto kelangkaan beras sebagai bahan makanan pokok bisa terealisasi sedikit demi sedikit.

\section{d. Demografi}

Jumlah penduduk pulau Lombok untuk saat ini kurang lebih 2.722.123 jiwa yang tersebar pada tiga kabupaten empat kabupaten dan satu kota madya, yaitu Lombok Timur, Lombok Tengah, Lombok Barat, dan Lombok Utara serta Kota Madya Mataram. Dimana sekitar $80 \%$ penduduk pulau ini adalah susu sasak, sebuah suku bangsa yang masih dekat dengan suku bangsa bali, tetapi sebagian besar memeluk agama Islam. Sisa penduduknya adalah orang Bali, Jawa, Tianghoa dan arab. Di Kabupaten Lombok Timur tercatan jumlah penduduknya secara keseluruhan berjumlah 1.033.669, dengan komposisi 474.714 jumlah laki-laki, dan 558.955 jumlah perempuan.

\section{SIMPULAN DAN SARAN}

Komponen dasar sistem sosio kultur terdiri dari suprastruktur idiologi, struktur sosial dan infrastruktur material. Komponen suprastruktur idiologi pada masyarakat sasak feodal, idiologi umum yang mereka yakini mengarah pada keyakinan akan kosmologi yang menyatu dengan dirinya. Sedangkan dalam ilmu pengetahuan mereka mengembangkannya melalui wadah pengajaran sifat dan sikap yang patuh pada norma adatistiadat yang berlaku dalam kehidupan masyarakat. Dalam bidang kesusastraan mereka mengenal lakak, cilokak dan cerita rakyat. Begitu juga dengan agama selalu menjadi pandua hidup mereka baik dalam urusan keduniaan lebih lebih untuk urusan alam baka.

Struktur sosial masyarakat pada masyarakat sasak terdapat juga stratifikasi sosial, baik antara sesama maupun stratifikasi dengan etnis yang berbeda. Di Lombok pemisahan antara masyarakat bangsawan sangat kentara. Misalnya dalam hal status sosial dan gelar yang mereka 
gunakan, serta hak atas kepemilikan mereka. Stratifikasi sosial tersebut pada bangsawan di Lombok misalnya yang paling tinggi mulai dari datu, raden, lalu, dan terakhir jajarkarang. Adapun pembagian kerja berdasarkan sek menematkan perempuan pada pekerjaan ganda baik di luar rumah seperti ikut bertani dan pekerjaan domestik. Bangsawan juga sangat memperhatikan garis kekeluargaan dan system kekerabatan yang mereka miliki. Begitu juga dengan infrastruktur masyarakat Sasak tradisional menggunakan teknologi yang relatif sederhana yang secara langsung menggunakan bahwan dari alam tempat tinggal mereka. Sehingga masyarakat tradisional selalu di identikkan dengan alam dimana mereka tinggal.

\section{DAFTAR RUJUKAN}

Budiwanti, Erni. 2002. Islam Sasak. LKIS, Yogyakarta.

Koentjaraningrat. 1996. Pengantar Antropologi I. Rineka Cipta, Jakarta.

Kuntowijoyo. 2005. Pengantar Ilmu Sejarah. Yogyakarta: Bentang.

Lukman, Lalu. 2005. Pulau Lombok Dalam Sejarah.

Muhsipuddin. 2004. Kilas Balik 100 Tahun Pendidikan di Lombok Timur.

Tamburaka, Rustam E.. 2002. Pengantar Ilmu Sejarah. Teori Filsafat Sejarah, Sejarah Filsafat dan IPTEK. Rineka Cipta, Sejarah.

Setiadi M. Elly. 2011. Pengantar Sosiologi. Jakarta: Kencana.

Soedjatmoko, Ali Muhammad, dkk (ed). 1995. Historiografilndonesia: sebuah pengantar. Gramedia Pustaka Utama: Jakarta. 